\title{
एउटा विचारको यात्रापथ कथामा समाख्यानशास्त्र
}

\author{
केशव पोखरेल \\ krpokharel@hotmail.com \\ सहप्राध्यापक \\ शिक्षाशास्त्र केन्द्रीय विभाग \\ त्रिभुवन विश्वविद्यालय
}

\begin{abstract}
लेखसार
आयामेली चिन्तक तथा प्रयोक्ता इन्द्रबहादुर राईद्वारा रचित 'एउटा विचारको यात्रापथ' कथालाई यस आलेखमा समाख्यानशास्त्रका आख्यान र अन्तअंख्यानका आधारमा अध्ययन गरिएको छ। प्रस्तुत कथाको समाख्याता 'म' पात्र रहेको, आख्यान र अन्तअंख्यानका अधिकांश कार्ययोजनामा उसैको सहभागिता देखिएको, फेरीवालप्रतिको टिप्पणी ₹ मूल्याङ्कनवाट उसको वैचारिकतामा परिवर्तन आएको र त्यसबाट आदर्शलाई पच्छ्याएर प्राकृतिकताको खोजीमा लागुुपर्ने दृष्टिकोणको संवाहक स्वयं समाख्याता नै भएकाले प्रस्तुत कथाको समाख्यान स्वकथनात्मक, खुला, उच्च, निकटवर्ती, पाठकमैत्री एवम् अरूका धारणाबाट भन्दा पनि स्वानुभवका आधारमा जीवनलाई हेर्ने दृष्टिकोणमा आधारित देखिन्छ।
\end{abstract}

मुख्य शब्दावली : आख्यानात्मक तह, कथनीयता, वाच्यत्व, समाख्याता, समाख्यानात्मक काल, स्वकेन्द्रण ।

\section{विषयप्रवेश}

इन्द्रबहादुर राई (वि.सं. १९५४-२०७४) आधुनिक नेपाली कथा, उपन्यास र समालोचना जगत्का चर्चित व्यक्तित्व हुन् । उनको सर्वप्रथम प्रकाशित कथा 'रातभरि हुरी चल्यो' (२०१६) हो। उनका विपना कतिपय (२०१६), कथास्था (२०२६) र कठपुतलीको मन (२०४६) गरी तिनवटा कथासड्ग्रह प्रकाशित छन् । उनले सुरुसुरुमा आधुनिक नेपाली कथाको सामाजिक र मनोवैज्ञानिक धारामा रहेर कथा लेखेका हुन् । उनका पछिल्ला चरणका कथाहरू आयामेली चिन्तन र लीलालेखनसँग सम्बद्ध छन् । कथास्था (२०२६) कथासड्र्रहमा सड्कलित प्रस्तुत 'एउटा विचारको यात्रापथ' कथामा आदर्श जीवनप्रतिको वितृष्णा र प्राकृतिक जीवनप्रति मोह व्यक्त गरिएको छ। चरित्रसहितको घटना वा कार्यको शृड्खलित रूपलाई कथा भनिन्छ। समाख्यानशास्त्र आख्यानात्मक संरचना भएको सिद्धान्त हो । यसमा कुनै कथ्य, लेख्य वा दृश्य संरचनाको वर्णनात्मक ढाँचा पहिल्याउने काम गरिन्छ। समाख्यानको व्याख्यामा त्यसका प्रकार्य र त्यस्ता सम्बन्धको निरूपण कसरी भएको छ भन्ने कुरामा जोड दिइन्छ। त्यस्तै समाख्यानशास्त्रभित्र आख्यानको विन्यासक्रम, कथाकथनभित्र वाचक, श्रोता, विषय, ठाउँ, काल, संरचना, कथनीयता आदिको खोजी गरिन्छ। यस आलेखमा पनि समाख्यानशास्त्रीय आधारमा 'एउटा विचारको यात्रापथ' कथाको विश्लेषण गरिएको हो। 


\section{समस्याकथन र उद्देश्य}

इन्द्रबहादुर राईका कथाहरूको विषयगत र वैचारिक दृष्टिकोणबाट अध्ययनहरू भएका छन् । उनी नेपाली कथापरम्परामा संरचनात्मक दृष्टिले नवीन प्रकृतिका कथा लेख्ने कथाकार हुन् । कथाको वाचनशैली, समाख्याताको उपस्थिति आदिका दृष्टिले उनका कथा अध्ययनीय छन् । त्यसैले उनको 'एउटा विचारको यात्रापथ' कथा पानि अध्ययनीय छ। तसर्थ प्रस्तुत अध्ययनपत्रको मुख्य समस्या नै उल्लिखित कथाको समाख्यानशास्त्रीय आधारमा विश्लेषण गर्नु हो र यही मूल समस्या समाधान नै अध्ययनको उद्देश्य पनि हो।

\section{पूर्वकार्यको समीक्षा}

समाख्यानशास्त्रबारे यसभन्दा पूर्व नेपाली साहित्यमा भएका केही कार्यलाई यसप्रकार देखाइएको छ :

गौतम (२०६९) ले 'समाख्यानात्मक वाच्यत्व' शीर्षकको आलेखमा सर्वप्रथम वाच्यत्वको सैद्धान्तिक चर्चा गरेका छन् । यस अध्ययनमा उनले पाश्चात्य समाख्यान शास्त्री जिनेट, लरेन्स, बाख्तिन, अक्जेल, च्याटम्यान आदिका दृष्टिकोण उल्लेख गरी समाख्यानमा समाख्याताको आवाज नै वाच्यत्व भएको र यसको निर्धारण समाख्यानमा को बोल्दै छ आधारमा हुने बताएका छन्। यस ऋममा उनले नेपाली कथा विधाका प्रतिनिधि कथाकार र तिनका प्रतिनिधि कथा पारिजातको 'मैले नजन्माएको छोरो', भिक्षुको 'सावित्रीको बाखो', प्रेमा शाहको 'पहैलो गुलाफ', विश्वेश्वरप्रसाद कोइरालाको 'मधेशतिर', मनु ब्राजाकीको 'एकान्त', विकलको 'लाहुरी भैंसी', इन्द्रबहादुर राईको 'खिर'जस्ता कथाबाट वाच्यत्व विश्लेषण गरेको पाइन्छ।

न्यौपाने (२०६९) ले 'खीर कथाको समाख्यानशास्त्रीय विश्लेषण' शीर्षकको लेखमा समाख्यानशास्त्रका आधारमा इन्द्रबहादुर राइै रचित प्रस्तुत कथाको आख्यानात्मक तह, समाख्यानात्मक वाच्यत्व, सड्केन्द्रण, समाख्यानात्मक काललाई अध्ययनको आधार बनाएको पाइन्छ। यस अध्ययनबाट चयनीय कथामा प्रथम तहको आख्यान, वाच्यत्व केन्द्रित समाख्याता, बहुलकेन्द्रण, सामान्य भूतकालीन क्रियाबाट अग्रभूमि निर्माण र अन्य पक्षवाट पृष्ठभूमि निर्माण भएको निष्कर्ष निकालिएको छ।

शर्मा (२०६९) ले 'मैले सरिताको हत्या गरे कथाको समाख्यान शास्त्र' शीर्षकमा गोविन्दबहादुर गोठालेद्वारा रचित उक्त कथाको समाख्यान शास्त्रीय अध्ययन गरेका छन् । यस अध्ययनमा उनले समाख्याता 'म' पात्र भएको र लैड़गिक दृष्टिले ऊ पुरुष रहेको, म पात्र नै घटनाको कर्ता, भोक्ता र द्रष्टा एवम् म पात्रको आप्नै कृत्य, त्यसको परिणाम र आफ्नै भविष्यप्रति अनभिज्ञ आफ्नै अस्वस्थ प्रेमी मानसिकता प्रस्तुत गरिएकाले यहाँ स्वकथनात्मक समाख्याता रहेको चर्चा गरिएको छ।

पौडेल (२०७०) ले 'मैले नजन्माएको छोरो कथाको समाख्यानशास्त्र' शीर्षकको आलेखमा उनले पारिजातद्वारा रचित उक्त कथाको समाख्यानशास्त्रका आधारमा विश्लेषण गरेका छन्। यस ऋममा एउटी अधबैंसे महिला समाख्याताको आन्तरिक मनोदशाको सफलतापूर्वक चित्रण गरिएको निष्कर्ष निकालिएको छ।

उपर्युक्त पूर्वाध्ययनबाट समाधेय समस्या समाधानका निम्ति निश्चित आधारढाँचा प्राप्त भएको छ। गौतमको आलेख समाख्यान शास्त्रबारे नेपालीमा लेखिएको पहिलो आधार हो भने त्यसैको जगमा टेकी न्यौपाने, शर्मा र पौडेलका समीक्षाहरू आएका हुन् । आजसम्मको सोधखोजअनुसार इन्द्रबहादुर राईको 'एउटा विचारको यात्रापथ' कथाको समाख्यान शास्त्रीय अध्ययन भएको देखिंदैन । त्यसैले गौतमको आलेखबाट सैद्धान्तिक आधार र अन्य लेखबाट विश्लेषणको ढाँचा लिई यहाँ उक्त कथाको अध्ययन गरिएको हो ।

\section{अध्ययनको औचित्य}


प्रस्तुत कथालाई समाख्यानशास्त्रका दृष्टिले वस्तुपरक विश्लेषण गर्नु यस अध्ययनको औचित्य हो । त्यसै समाख्यानशास्त्रका समाख्याता, वाच्यता, सङ्केन्द्रण, काल, कथनीयता आदिको प्रामाणिक अध्ययनबाट यस विषयमा ज्ञानात्मक नवप्रवर्तन हुने भएकाले यस अध्ययनको औचित्य स्वतः पुष्टि हुन्छ। यस अध्ययनले आख्यानात्मक कृतिको समाख्यानात्मक विश्लेषण गर्न चाहने शोधार्थी, पाठक, समीक्षकका लागि सहयोग पुग्ने भएकाले व्यावहारिक दृष्टिले पनि यो अध्ययन उपयोगी देखिन्छ।

\section{अध्ययनको सीमा}

प्रस्तुत आलेखमा शोध्य समस्याको अध्ययन समाख्यानात्मक तह, समाख्याता, समाख्यानात्मक वाच्यत्व, समाख्यानात्मक सङ्केन्द्रण, समाख्यानात्मक काल व्यवस्था र कथनीयताका आधारमा मात्र गरिएको छ। समाख्यानात्मक विधि,स्थान र परिवेशका आधारमा अध्ययन गरिएको छैन। यसो गर्नु यस शोधकार्यको क्षेत्र र सीमा पनि हो ।

\section{शोधविधि}

प्रस्तुत अध्ययनमा उपयोग गरिएको शोधविधिलाई सामग्री सङ्कलन विधि तथा अध्ययनको सैद्धान्तिक पर्याधार र ढाँचा गरी छुट्छाछुट्टे उपशीर्षकमा प्रस्तुत गरिएको छ।

\section{सामग्री सङ्कलन विधि}

प्रस्तुत आलेखका लागि मूल समस्यासँग सम्बन्धित सामग्रीको सड्कलन इन्द्रबहादुर राईको 'एउटा विचारको यात्रापथ' कथाको सम्यक् पठनबाट लिइएको छ। यस कममा समाख्यानशास्त्रीय ग्रन्थ र तत्सम्बन्धी प्रायोगिक आलेखहरूलाई पनि अध्ययनको आधार बनाइएको छ।

\section{सैद्धान्तिक पर्याधार र विश्लेषणको ढाँचा}

आख्यानको सैद्धान्तिक अवधारणाको व्याख्या गर्ने शास्त्रलाई समाख्यानशास्त्र भनिन्छ। यसमा आख्यानात्मक संरचनाको विश्लेषण गरिन्छ । अरिस्टोटलले साहित्यिक अभिव्यक्तिलाई मिमेसिस (अनुकरणमूलक) र डाइजेसिस (समाख्यानमूलक) गरी दुई किसिमबाट वर्गीकरण गरेका छन् । यसैलाई आधार बनाएर च्याटमानले महाकाव्यात्मक आख्यान, उपन्यास, लघुकथा आदिलाई आख्यानपरक समाख्यानात्मक विधा र नाटक, फिल्म कार्टुन आदिलाई मिमेटिक आख्यानात्मक विधा गरी छुट्याएको पाइन्छ। समाख्यानको शब्दको प्रयोग आख्यानात्मक विधाका रूपमा सर्वप्रथम सन् १९६६ मा कम्युनिकेसन (फ्रेन्च पत्रिका) बाट सुरु भएको हो र यसको तिन वर्ष पछाडि आख्यान सिद्धान्तका रूपमा समाख्यानशास्त्र प्रारम्भ भएको पाइन्छ। समाख्यान के हो भन्ने विषयमा पाशचात्य विद्वान्हरूका बिचमा मतान्तर छ। जेराट जेनेटजस्ता कतिपय समाख्यानशास्त्रीहरू शाब्दिक रूपमा आख्यायित पाठलाई समाख्यानको संज्ञा दिन्छन् भने रोला वार्थ, च्याटमान, बल जस्ता समाख्यानशास्त्रीहरू जुनसुकै विधाका माध्यमबाट प्रस्तुत हुने अन्तर कथायुक्त रचनालाई समाख्यान भन्न चाहन्छन् (गौतम, २०६९, पृ. १)। यस आधारमा समाख्यान भनेको कथा प्रस्तुत गर्ने कुनै पाठ, तस्विर, संवाद वा यी सबैको समष्टिरूप भएको रचना मान्न सकिन्छ। त्यसैले उपन्यास, नाटक, फिल्म, प्रहसन र कथात्मकतासहितको लामो कविता, खण्डकाव्य, महाकाव्यसमेत समाख्यान हुन् । समाख्यानमा मूलतः कथा केन्द्रमा रहन्छ, र त्यसमा चरित्रले गरेका कार्य, प्राकृतिक घटनाहरू समावेश हुन्छन् । पछिल्लो समयमा समाख्यानशास्त्रमा लेख्य रूप, कथ्य रूप, चित्र रूप (स्थिर र सख्चलित), सान रूप आदिको मिश्रित अभिव्यक्ति पाइन्छन्। रोला वार्थका अनुसार समाख्यान मानवताको विकाससँगै सुरु भएको हो र यसका रूपहरू सबै सबै समयमा, सबै ठाउँमा र सबै समाजमा पाइन्छन्। समाख्यान सबै प्रकारका 
आख्यानसँग सम्बन्धित हुन्छ। यो साहित्यिक र साहित्येतर आख्यानात्मक तथा आख्यानेतर र भाषिक तथा भाषेतर रूपमा वर्गीकत छ। समाख्यानशास्त्र भित्र समाख्यानात्मक तह, वाच्यत्व, सङ्केन्द्रण, समाख्यानात्मक काल, कथनीयता आदि पर्दछन् (गौतम, २०६९, पृ. २)। यिनै विभिन्न पक्षमा आधारित भई प्रस्तुत आलेख तयार गरिएको छ र यसका आवश्यक प्रतिमानहरूलाई तत्तत् स्थानमा उल्लेख गरिएको छ।

\section{एउटा विचारको यात्रापथ कथाको समाख्यानात्मक विश्लेषण}

समाख्यानात्मक विश्लेषणमा आख्यानात्मक तह, समाख्याता, वाच्यत्व, सङ्केन्द्रण, काल र कथनीयताका मान्यता मान्यता स्थापित गरिएको छ र तिनै मान्यताका आधारमा विवेच्य कथाबाट उद्गार लिई तिनको विश्लेषण गरिएको छ।

\section{आख्यानात्मक तह}

कुनै पानि समाख्यानात्मक सन्चरणमा आख्यानका विभिन्न तह हुन्छन् । रोला वार्थले कथाभित्र कथा र त्यस कथाभित्र पनि कथा हुन सक्छ भनेका छन्। आख्यानभित्र आउने कथाहरू एकल आख्यान र गर्भाख्यान गरी दुई किसिमका हुन्छन् । मूल वा एकल कथा फ्रेम वा ग्याट्रिक्स आख्यान हो भने त्यसभित्र टाँसिएर आउने अर्को कथा गर्भाख्यान वा हाइपो आख्यान हो। गर्भाख्यानभित्र पनि एकभन्दा धैरै कथाहरू आउन सक्छन्। त्यस्ता कथालाई हाइपो हाइपो आख्यान पनि भनिन्छ। समाख्यानात्मक फ्रेम (मूल कथा) को कथावाचकलाई प्रथम स्तरको समाख्याता, आश्रित वा हाइपो स्तरको समाख्यातालाई द्वितीय स्तरको समाख्याता र हाइपो हाइपो स्तरको समाख्यातालाई तृतीय स्तरको समाख्याता भनिन्छ। जेनेटले प्रथम स्तरको समाख्यातालाई बहिर्निष्ठ (एक्स्ट्रा डाइजेटिक), द्वितीय स्तरको समाख्यातालाई अन्तर्निष्ठ (इन्ट्राडाइजेटिक) र तृतीय स्तरको समाख्यातालाई अन्तअर्न्तनिष्ठ (इन्ट्राइन्ट्रा डाइजेटिभ) भनेको पाइन्छ। अन्तर्निष्ठ र अन्तअर्त्तनिष्ठ समाख्याता बहिर्निष्ठ आख्यानका पात्र हुन्। दोस्रो स्तरको आख्यानको समाख्याताले तेस्रो स्तरको समाख्याता निर्धारण गरी कथा भन्न लगाउँछ, त्यो कथा मूल कथाको प्रसड़्नमा नै गएर जोडिएको हुन्छ।

समाख्यानात्मक शृडखलाभित्र सम्प्रेषणका विभिन्न तह, ती तहमा रहेका सम्बोधक र सम्बोधित समाख्याताको भूमिकाजस्ता विविध पक्षको अध्ययन गरिन्छ। प्रस्तुत कथाको समाख्यानात्मक शृड्खलाका तहमा गैरआख्यानात्मक, आख्यानात्मक र कार्यात्मक गरी सन्चरणका तिन तह रहेका छन्। पहिलो तह गैरआख्यानात्मक सन्चरणको तह हो । यसमा कथाकार राई र कथाका जुनसुकै पाठक रहेका हुन्छन् । स्रष्टाले कृति सिर्जना गर्ने र पाठकले पढ़ने भए पनि यी दुबैले आफैं आख्यानात्मक सन्चरण गर्दैनन् । त्यसैले स्रष्टा राई र पाठकका बिचको सन्चारलाई गैरआख्यानात्मक तह मानिन्छ। समाख्यानात्मक शृड्खलाको दोस्रो तह आख्यानात्मक सन्चरण हो। यसमा समाख्याता र अज्ञात सम्बोधित (समाख्याता (म) ..... उसको बाबु, म ..... उसकी आमा, म ..... फेरीवाल, म ..... ठेकेदार, म ..... दाजु ) रहेका हुन्छन् । प्रस्तुत कथामा समाख्याता (म पात्र) ले आफ्नो जीवनमा घटेका महत्त्वपूर्ण घटना, जिज्ञासा वा विचार सम्बोधितलाई सन्चरण गरेकाले यसको भूमिका महत्त्वपूर्ण रहेको छ। समाख्यानात्मक सन्चरणको तेस्रो तहलाई कार्यात्मक भनिन्छ। विवेच्य कथामा समाख्याता नै यस तहमा पात्रका रूपमा उपस्थित छ। यस कथाको संरचनामा जम्मा १०९१ शब्दहरू रहेका छन्। यी शब्दमध्ये समाख्याताको प्रस्तुतिमा ९६६ शब्द र अन्य पात्रको प्रस्तुतिमा १०३ शब्द आएका छन्। समाख्याताको आत्मप्रस्तुति नै प्रस्तुत कथाको मुख्य आख्यान हो र यसबाहेक अरू पात्रहरू सीमित स्थानमा आएका छन् । खास गरी म पात्र (समाख्याता), उसको बाबु, उसकी आमा, फेरीवाल, घरमालिक ठेकेदार, सुके बजारमा भेटिएको दाजुका बिचमा भएका सन्चरण आख्यानका कथांशहरू हुन्। यी कथांशहरू समाख्याताको कथनपछि कथानकलाई गतिशील 
तुल्याउन र प्रभावकारी बनाउन पात्रहरूको कथन र त्यसपछि, समाख्याताको कथन शृड्खला रहेको छ। तसर्थ यस कथामा गर्भाख्यानको शृड्खलाभन्दा पनि अन्तअख्यानको शृड्खला रहेको देखिन्छ।

\section{समाख्याताको पहिचान}

समाख्यानशास्त्रमा समाख्याताका माध्यमबाट समाख्यानात्मक सङ्कथन प्रस्तुत गरिएको छ। समाख्याता पाठको वर्णनकर्ता हो। ऊ पात्रका रूपमा आउन पनि सक्छ र नआउन पनि सक्छ। ऊ पाठको स्रष्टा वा भोक्ताका रूपमा पनि उपस्थित हुन्छ। क्रियात्मक भूमिका विहीन कथाको प्रस्तोताको रूपमा मात्रै पनि समाख्याता आउन सक्छ। समाख्याताको पहिचान सर्वनाम, सम्बोधन र आदरार्थीका विभिन्न रूपबाट गर्न सकिन्छ। भाषिक सड्केतक नभएका कतिपय ठाउँमा संवेगात्मक, भावनात्मक र वर्णनात्मक सूचनाबाट पनि समाख्याताका गुणको पहिचान हुन सक्छ।

प्रस्तुत कथामा समाख्याता स्वयम् 'म' पात्रका रूपमा उपस्थित छ। समाख्यानात्मक सन्चरणका लागि उसको भूमिका महत्त्वपूर्ण हुन्छ, । समाख्याताको मानसिकता र क्रियाकलाप तलका उद्गारमा यसरी देखाइएको छ :

9 "यो निराश कुन्ठिएको विचार टुकुलटुकुल दगुर्दे मेरो मनमा कहाँदेखि आज आएको छ, म यसलाई पैल्याउँछु " (अनु. २)।

२ “फेरीवाललाई हेर्दा देखिन्छ पनि, मलाई यो निकै अन्धकार लाग्यो" (अनु. ४) ।

३ “आज पनि मेरो जोगी फेरी बजाएर रातमा समग्र दून्द्री शक्तिहरूलाई आह्वान गरेर हिँड्छ” (अनु. १६)।

$\checkmark$ “तीस जना फेरीवाल एक ठाउँमा, मलाई त्यो सड्ख्या र जमात नै घिन लाग्दो लाग्यो" (अनु. २ू)।

y "एउटा आदर्श, मेरो एउटा रहस्यको आज पतन भयो, भोलि अर्को एउटा हुन्छ, पछिपछि, मेरा सबै आदर्शहरू सिद्धिन्छन् ... " (अनु. २९)।

६ “जीवन तर त्यसै बाँचिन्छ, यसमा आदर्श र सिद्धान्तहरूले घेरा हाल्नुपर्देन” (अनु. ३३)।

उपर्युक्त उद्गारले समाख्याताको जीवन र जोगीसम्बन्धी मानसिकता प्रस्तुत गरेका छन् । सानो छँदा समाख्याताले जोगीलाई अलौकिक शक्ति ठानेको र पछि, उसलाई देख्न सकिन्छ भन्दा आश्चर्य मानेको छ। अभ जोगीले शक्ति प्राप्त गरी गाउँको रक्षा गई भन्ने ‘म' पात्र वा समाख्याताको धारणा धेरै जोगीको समूह देख्दा र उनीहरूको यथार्थता बुऊदा विघटित हुन पुग्छ। यसरी जीवन बचाइका ऋममा निर्माण गरिएका आदर्शहरू भत्किँदै गएको सन्दर्भलाई समाख्याताले तलका उद्गारमा प्रस्तुत गरेको पाइन्छ :

9 "दिनेपिच्छे छोरीलाई स्कुल पठाउनु, त्यसले मलाई आप्नो पेटी बाँधिमाग्छ, त्यो स्कुल जान्छ ... " (अनु. १)।

२ “... फेरीवालले फेरी लाउँदा पनि म जाग्छु, सजिलो फेरीवालाले फेरी फुक्छ, घर वरिपरि घुम्दे गहिरो गुनगुनाउँछ, म बुकिदन"” (अनु. ३)।

३ "एक दिन म सिमाना बजार पुगेको थिएँ" (अनु. १७)।

$\checkmark$ "मेरो खुट्टाले मान्छे, कुल्च्यो" (अनु. १४)।

y "मैले रोके, अनि एक दाना इस्कुस टिपेर गएँ, त्यही दिएँ" (अनु. ३१)।

उपर्युक्त उद्गारमा समाख्याताले म पात्रका क्रियाकलापलाई प्रस्तुत गरेको छ। म पात्रले छोरीलाई पेटी बाँधिदिएर स्कुल पठाएको, फेरीबाट निस्केको आवाजबाट आफू जागेको, जोगीको गुनगुनाहट केही पनि 
नबुक्केको, सिमाना बजार गएको, त्यहाँ अँध्यारा कोठामा सुतेका जोगीहरूलाई कुल्चेको र नानीहरूकी आमालाई रोकी आफूले एक दाना इस्कुस फेरीवाललाई दिएको क्रियाकलाप आएको छ।

यसरी समाख्याताको मानसिकता र क्रियाकलापका अध्ययनवाट समाख्याताको पहिचान स्पष्ट भएको छ। यस कथाको समाख्याता म पात्र हो। ऊ यस कथाको प्रमुख पात्र पनि हो। आफ्नो जीवन र जोगीलाई हेर्ने दृष्टिकोणमा आएको परिवर्तनलाई पनि उसले स्पष्ट पारेको देखिन्छ।

\section{समाख्यानमा वाच्यत्व}

पाठमा को बोल्दै वा कसले कथा भन्दै छ भन्ने कुरा केन्द्रमा राखेर कुनै पनि पाठको वाच्यत्व निर्धारण गरिन्छ। जेनेटले समाख्याताले नै समाख्यानको विचार, भाव आदिको सम्यक् जानकारी पाठकसँग गराउने हुनाले समाख्याताकै माध्यमबाट वाच्यत्व प्रकट हुन्छ भनेका छन् । लरेन्सका अनुसार आख्यानात्मकतामा वाच्यत्वको सन्दर्भ पाठमा प्रस्तुत गरिएको पात्रको कथ्य (भोकल) गुण र गतिसम्बन्धी स्वरगत (टोनल) गुणसँग सम्बद्ध हुन्छ। मिखाइल वाख्तिनले भने वाच्यतालाई पाठनिष्ठ र अन्तर्पाठात्मक स्तरमा विभक्त गरेका छन्। उनले पाठनिष्ठ वाच्यताअन्तर्गत समाख्याता (कथावाचक) र पात्रलाई राखेका छन् भने अन्तर्पाठात्मक वाच्यतामा लेखकलाई राखेका छन्। एकभन्दा बढी पाठनिष्ठ वाच्यतामा समायोजनको काम लेखकबाट गरिएको हुन्छ। आत्मजीवनी (आत्मकथा र आत्मसंस्करण) वा व्यक्तिवृत्तात्मक (जीवनीपरक) समाख्यानमा पाठमा रहेको नाम र व्यक्तिको वास्तविक नाम उही हुन सक्छ। लेखकीय वाच्यता पनि समाख्याताको वाच्यताका रूपमा आउन सक्छ। त्यसकारण समाख्यानमा आउने लेखकीय वाच्यता र समाख्याताको वाच्यताका बिचमा भिन्नता रहन्छ। समाख्याताको वाच्यत्व पहिचान गर्न समाख्याताको परिवेश, विचार, जीवनभोगाइ, मूल्यमान्यता वा दृष्टिकोणका बारेमा जानकारी राख्नुपछ। समाख्याताको आवाज र भुकाव एवम् लैड़िक अवस्थाका आधारमा पनि कथयिताको पहिचान गर्न सकिन्छ। आख्यानमा प्रथम पुरुषको समाख्याता भए क्रियापदका आधारमा र तृतीय पुरुषको समाख्याता भए संवेग, भावना, वर्णनात्मक सूचनाका आधारमा लैड्रिक अवस्था छुट्याउन सकिन्छ। पाठमा प्रयुक्त लेखकको वास्तविक विचार पाठकसामु समाख्याताकै माध्यमबाट पुग्छ। त्यसैले पाठमा समाख्याताले व्यक्त गरेको आवाजलाई वाच्यत्व भनिन्छ।

प्रस्तुत कथामा समाख्याताको जीवन भोगाइका क्रममा आएका र विकसित मान्यताहरू नै वाच्यत्व हुन् । कथाको प्रारम्भमै समाख्याताको जीवनसम्बन्धी चिन्तन यसरी प्रकट भएको छ : "दिनै पिच्छे छोरीलाई स्कुल पठाउनु, त्यसले मलाई आफ्नो पेटी बाँधी माग्छ, त्यो स्कुल जान्छ, यै जीवन हो र यति मात्र जीवन हो" (अनु. १) । यस कथामा समाख्याताले आफू सानो छँंदा फेरीवालसँग डराउनु, बाबुसंग फेरीवालका बारेमा प्रश्न गर्नु, भोलिपल्ट आमाले फेरीवाललाई सामान दिँदा दुलोबाट हेर्नु, रातको समयको फेरीवाल फेरी बजाउँदै एक्लै हिंडेको देख्दा उसलाई महान् ठान्नु, फेरीवाल शिवको अनुचर भएको र त्यसले हाम्रो भूतप्रेत धपाई गाउँको संरक्षण गई भन्ने धारणा राखद्दै आएकामा ठेकेदारका घरको कालो कोठामा फेरीवालको जमात र तिनीहरूको यथार्थता बुऊदा र देख्दा फेरीवालप्रतिको आस्था घृणामा परिणत हुन्छ। ऊ भन्छ, "मेरो फेरीवाल एउटा हुन्थ्यो, एक्लै हिँड्य्यो, अर्को फेरीवाल उसले थाहा पाएको हुँदैनथ्यो" (अनु. २ू)। यसरी समाख्याताको फेरीवालप्रतिको दृष्टिकोणमा आएका परिवर्तनको सूचना यस कथामा दिइएको छ। यस्ता सूचनाबाट जोगीहरू पनि जीवन बचाइका कममा गर्नुपर्ने एउटा कर्म गरिरहेका छन् भन्ने धारणा विकसित हुन्छ। आफ्ना धारणाहरू विखण्डित हुँदै जाँदा समाख्याता हताश हुन पुग्छ र उसले विनाआदर्श पनि जीवन चल्दो रहेछ भन्ने ज्ञान पाउँछ। यस ज्ञानले आदर्शविनाको प्राकृतिक जीवन नै सुखद हुने निष्कर्षमा समाख्यातालाई पुय्याएको छ। 
प्रस्तुत कथामा म पात्रका माध्यमबाट समाख्याताको दृष्टिकोण, धारणा वा विचार प्रकट भएको देखिन्छ । अन्य पात्रहरूमा फेरीवालको भूमिका अलि बढिरहेको छ भने बाँकी पात्रहरू समाख्याताका सूचनाको पुस्ट्याइंका निम्ति मात्र उपस्थित भएका छन् । त्यसैले यस कथामा समाख्यानात्मक, अन्तर्पाठात्मक र पाठेतर वाच्यत्वमध्ये समाख्यानात्मक वाच्यत्व रहेको छ। त्यस्तै यस कथाको समाख्याता म पात्रका रूपमा उपस्थित भएको छ र लैड्रिक दृष्टिले ऊ पुरुष पात्र हो । कथामा प्रयुक्त 'म डराएको थिएँ', 'म वाँचेको छु', ‘चोइटिएर पनि पूरै छु’ जस्ता क्रियापद र 'नानीहरूकी आमा' भनेर अरू कसैलाई सम्बोधन नगरी आफ्नै श्रीमतीलाई सड्केत गरेकाले समाख्याता कम्तीमा दुई सन्तानको बाबु भएको सूचना प्रकट हुन्छ। यसले पनि समाख्याता पुरुष नै भएको तथ्यलाई पुष्टि गई। यसरी समाख्याताको विचार, आदर्श वा धारणासम्बन्धी सूचना नजिकैबाट देख्न सकिने भएकाले प्रस्तुत कथाको समाख्यानात्मक वाच्यता उच्च र निकटवर्ती रहेको पाइन्छ।

\section{समाख्याताको खुला अवस्था}

पाठमा समाख्याताको उपस्थिति कसरी सूचित गरिएको छ, त्यसका आधारमा समाख्यातालाई बन्द र खुला गरी हेर्न सकिन्छ। समाख्याता पाठभित्र धेरै अंश बोल्छ भने उसका बारेमा धेरै कुरा थाहा पाउन सकिन्छ। म, हामीका रूपमा आफ्नो सन्दर्भ जनाउने समाख्याता प्रायः खुला हुन्छ। यस्तो समाख्याता पाठक वा श्रोतामैत्री हुन्छ। यसमा समाख्याताको दृष्टिकोण, मान्यता, टिप्पणी र स्वभाव खुला रूपमा देख्न सकिन्छ। खासगरी आलड्कारिक वा चित्रात्मक अभिव्यक्तिमा, काल्पनिक वा विम्बात्मक अभिव्यक्तिमा, मूल्याङ्कनपरक पदावलीमा, संवेगात्मक अभिव्यक्तिमा समाख्याता खुला हुन्छ र त्यहाँ पात्रहरू कमै हुन्छन् ।

प्रस्तुत कथाको समाख्याता म पात्र हो। कथाको नब्बे प्रतिशतभन्दा बढी अंश उसैले नै प्रस्तुत गरेको छ। त्यसबाहेक यस कथाका अन्तर्भख्यानात्मक संवादमा पनि समाख्याताकै विचार अगाडि बढाइएको छ। फेरीवालप्रति समाख्याताको मूल्याङ्कनपरक दृष्टिकोण रहेको छ। यस कथामा म पात्रको जीवनमा आएको वैचारिक परिवर्तन र जीवनप्रतिको पुनव्याख्या स्पष्ट देख्न सकिन्छ। यसरी समाख्याताले पात्रको टिप्पणी गर्नाका साथै घटनाको विकासमा पनि आफू नै संलग्न भएको हुँदा प्रस्तुत कथाको समाख्याता खुला र पाठक मैत्री रहेको देखिन्छ।

\section{स्वकथनात्मक समाख्याता}

कथा संसारमा समाख्याताको उपस्थितिलाई आधार बनाएर स्वकथनात्मक र परकथनात्मक भेद निर्धारण गरिन्छ। आख्यानमा समाख्याता ‘म’ पात्रका रूपमा उपस्थित भई गरिएका कार्यात्मक वाक्यहरू प्रथम पुरुषका हुन् भने त्यसलाई स्वकथनात्मक (होमो डाइजेटिक) समाख्याता भनिन्छ। कहिलेकाहीं समाख्याता प्रथम पुरुष सर्वनाममा आएको छ तर त्यो आफ्नो कथाको संसारमा अनुपस्थित भएमा त्यसलाई परकथनात्मक (हेटोडाइजेटिभ) समाख्याता भनिन्छ। यस किसिमका कथामा कार्यात्मक वाक्यहरू तृतीय पुरुष सर्वनामका हुन्छन्। प्रस्तुत कथाका कार्यात्मक वाक्यहरू प्रथम पुरुष सर्वनामका रूपमा आएका छन् :

9 “सानोमा पहिलो राति फेरीवाललाई सुन्दा म डराएको थिएँ र बाबुको छेउँमा पुगेको थिएँ" (अनु. ४) ।

२ "मैले भित्रै भित्ताको दुलोदेखि हेरें। आमाको साल हो कि फेरीवालको लुगा देखें, सेतोसेतो के देखे" (अनु. ६) ।

३ “म उभिएँ रोकिएर" (अनु. १९)।

$\checkmark$ “यो धक्का सहेर म धैरै बलियो भएको छु र आज कन् भन्छु - मान्छेसँग पहिले आदर्श थिएन " (अनु. ३३)। 
उपर्युक्त उद्गारका आधारमा प्रस्तुत कथाको समाख्याता प्रथम पुरुषवाचक सर्वनाम 'म' हो र ऊ आफैं आख्यानमा उपस्थित भई घटनाको साक्षी भएर कथा आएकाले प्रस्तुत कथाको समाख्याता स्वकथनात्मक (होमो डाइजेटिभ) रहेको देखिन्छ।

\section{समाख्यानमा सङ्केन्द्रण}

सङ्केन्द्रण वा फोकलाइजेसनलाई व्याकरणात्मक कोटिका रूपमा लिएको पाइन्छ। सड्केन्द्रणले त्यस्तो क्रियारूपलाई विशिष्टीकृत गई, जसले तथ्यको प्रस्तुति, आज्ञा, सम्भावना, इच्छा आदिका सुनिश्चितताको मात्रालाई जनाउँछ। पाठको केन्द्रीय अभ्युदेश्यीय अभिमुखीकरण कसले प्रदान गरेको छ, त्यसैसँग सङ्केन्द्रणको सम्बन्ध रहन्छ। समाख्यानात्मक सूचनालाई कुन व्यक्तिका ज्ञान वा दृष्टिकोणका आधारमा सङ्कुचित तुल्याइएको छ, भन्ने कुरा हेरिन्छ। पाठको अभ्युद्देशीय अभिमुखीकरण गर्ने व्यक्ति समाख्याता नै हो। ऊ बाहेकका अन्य पात्रहरू पनि पाठको अभ्युद्देश्यीय अभिमुखीकरणका रूपमा आएका हुन्छन् । यसरी कुनै व्यक्तिका माध्यमबाट घटनालाई हेर्ने, सङ्केन्द्रित गरिने अभिकर्तालाई विन्यस्त गर्ने र उसको सहानुभूति अनुसारको दृष्टिकोण प्रस्तुत गर्ने सन्दर्भमा सङ्केन्द्रण अभिव्यक्त भएको हुन्छ। पाठ वा आख्यानमा विभिन्न प्रकारका सङ्केन्द्रणहरू रहन्छन् ।

आख्यानमा एउटा पात्र वा समाख्याताबाट स्थिर रूपमा एउटै विचार प्रस्तुत भएको अवस्था एकल सङ्केन्द्रण हुन्छ। आख्यानका विभिन्न अंश वा पक्षमा बेग्लाबेग्लै सङ्केन्द्रण वा पात्रहरू प्रस्तुत भएको बेग्लाबेग्लै विचार वा चिन्तनलाई चल सङ्केन्द्रण भनिन्छ। यसमा एकभन्दा धैरै पात्रका विचारहरू रहन्छन्। एउटा विषयमा प्रत्येक पात्रले छुटाछुछै दृष्टिकोण प्रस्तुत गर्नु वा विभिन्न पात्रहरूले विभिन्न कोणबाट एउटै विचारमा दृढ हुनु बहुसङ्केन्द्रण हो। कुनै आख्यानमा पात्रको समूहबाट व्यक्त गरिएको एउटै विचार वा दृष्टिकोणलाई सामूहिक सङ्केन्द्रण भनिन्छ। कुनै काल्पनिक वा पात्र वा सङ्केन्द्रणबाट मूल विचार प्रस्तुत गरिएमा आनुकाल्पनिक सड्केन्द्रण हुन्छ। जुन पाठमा सङ्केन्द्रणको प्रयोग हुँदैन, त्यसमा सड्केन्द्रण रहँदैन अथवा पात्रहरूका अभावबाट मुख्य विचार प्रकट भएमा त्यसलाई शून्य सङ्केन्द्रण भनिन्छ।

प्रस्तुत कथामा समाख्याताका माध्यमबाट घटनाहरू प्रस्तुत गरिएको छ। 'म' पात्रका आएको समाख्याताका दृष्टिकोणले समाख्यानात्मक पाठलाई डोय्याएको छ। समाख्याताले जीवन र जोगीसम्बन्धी आफ्नो विचार प्रस्तुत गर्ने कममा आवश्यकताअनुसार फेरीवाल, आफ्ना आमाबाबु, ठेकेदार र दाजुजस्ता पात्रहरूको चयन गर्ने र उनीहरूलाई प्रस्तुत गर्ने कार्य गरेको छ। पात्रहरूलाई छोटाछोटा क्रियाकलापमा संलग्न गराई आप्नो विचार वा दृष्टिकोण समाख्याताले अगाडि बढाएको छ। त्यसैले प्रस्तुत कथाको फोकलाइजर वा सङ्केन्द्रक समाख्याता हो भने उसका दृष्टिकोण, विचार वा अनुभूति सङ्केन्द्रणीय विषय हुन् । समाख्याताको फेरीवालप्रतिको आस्था र विश्वास ठेकेदारको घरमा कुप्रिएर र तन्किएर सुतेका फेरीवालहरू देखेपछि विखण्डित हुन्छ। मानिस आदर्शप्राप्तिका निम्ति यथार्थबाट टाढिएको छ। आदर्शविना पनि जीवन बिताउन सकिन्छ भन्ने कुरामा समाख्याताको टिप्पणी यस्तो छ :

मेरो एउटा आदर्श चकनाचुर भएको थियो अवश्यै, तर म जुन मानिस हुँ (र मानसिकता) अलिकति पनि चोइटिएको छैन रहेछ, (म बाँचेको छु, चोइटिए पानि पूरै छु), दैलोमा मैले हर्ष र बल पाएँ, एउटा के साराका सारा आदर्शहरू नष्ट भएपछि पनि मानिसको मानसिकता सिड्जो नै रहने रहेछ। (अनु. ३२)

मानिस दुःख र पीडा मिश्रित बाध्यात्मक परिस्थितिमा मात्र यथार्थ जीवन बाँच्न सक्छ । समाजका तथाकथित मानिस वा तिनको व्यवहारलाई आदर्श बनाई तिनको अनुकरण गर्नुभन्दा अधिकांश मानिसले भोगेजस्तै व्यावहारिक जीवनको उपयोग उचित हुने कुरामा समाख्याताको भनाइ यस्तो छः 
यो धक्का सहेर म धेरै बलियो भएको छु र आज भन् भन्छु - मान्छेसँग उहिले आदर्श थिएन तर जीवन साँचो र पूर्ण थियो उसको। थिएन भन्नु जीवनप्रति व्लास फेमी हो। आदर्शहरू बटुल्ने राम पछि, हुँदै आएछ, र थपिंदै आयो। जीवन तर त्यसै बाँचिन्छ, यसमा आदर्श र सिद्धान्तहरूले अर्थ हाल्नु परैै। । (अनु. ३३)

आदर्श जीवनप्रतिको असहमति र व्यावहारिक जीवनप्रतिको सहमति नै यस कथाका समाख्याताको दृष्टिकोण हो। कथाको समग्र पाठलाई यही दृष्टिकोणले डोयाएको हुँदा प्रस्तुत कथाको सड्केन्द्रक वा फोकलाइजर समाख्याता हो र उसका दृष्टिकोण, विचार वा चिन्तन नै फोकलाइज्ड विषय वा सङ्केन्द्रणीय पक्ष हुन् ।

\section{समाख्यानात्मक काल}

कुनै पनि आख्यानमा प्रयुक्त काललाई समाख्यानात्मक काल भनिन्छ। यो कथाको समय विश्लेषणसँग सम्बन्धित छ। आख्यानमा कार्य कहिले घटित भएको हो, घटना कति समय भएको हो, घटना कतिपल्ट आवृत्त भएको भन्ने कुराको जानकारी समाख्यानात्मक कालबाट पाइन्छ। आख्यानमा समयको सन्दर्भ विन्दु, कार्यविधि र त्यसको आवृत्तिले महत्त्वपूर्ण भूमिका खेल्दछ। परम्परित कथामा प्राकृतिक अनुक्रमको अनुसरण गरिएको हुन्छ भने प्रयोगवादी प्रकृतिका कथामा प्राकृतिक समयक्रम खजमजिएको हुन्छ। यस्ता कथामा पूर्वस्मृति वा पश्चदीप्तिको प्रयोग गरी समाख्यानात्मक कम मिलाइएको हुन्छ। समाख्याताले पाठक वा श्रोतालाई ध्यानमा राखेर समाख्यानात्मक कालको चयन गरेको हुन्छ। कथामा घटनाको प्रस्तुतिगत काल वा समय समाख्यानात्मक कालसँग सम्बद्ध हुन्छ। घटनाबोधक क्रिया भूतकालमा छ भने समाख्यानात्मक काल भूत र अभूत कालमा छ, भने समाख्यानात्मक काल अभूत हुन्छ। समाख्यानमा एउटा कालको प्रयोग हुँदाहुँदै अचानक अर्को काल वा पक्षको प्रयोग हुन सक्छ। आख्यानमा समाख्यानात्मक कालअन्तर्गत भूत र अभूत काल आए पनि कथाको पृष्ठभूमि वर्णन, स्थिति वर्णन, परिस्थिति चर्चा, प्रभाव, असर वा मूल्याड्कन, टिप्पणी आदिको प्रस्तुतिमा विभिन्न पक्षगत संरचनाको प्रयोग हुन्छ। कथाको अग्रभूमि निर्माणमा एकै कालिक संरचनाको प्रयोग हुन्छ भने पृष्ठभूमि निर्माणमा तत्काल बोध भएको स्थितिमा अज्ञात पक्ष, अतीत स्मृतिका रूपमा अभ्यस्त पक्ष, स्थिति वर्णनमा अभ्यस्त पक्ष र संवाद संरचनाका ऋममा आज्ञा, इच्छा, सम्भावना जस्ता भावहरू प्रयोगमा आउन सक्छन् ।

प्रस्तुत कथामा अग्रभूमि निर्माण, पृष्ठभूमि निर्माण, स्थिति वर्णन, मनस्थिति वर्णन एवम् परिवेश प्रस्तुति आदिमा विभिन्न कालिक पक्षको प्रयोग गरिएको छ। प्रस्तुत कथाले समेटेको समाख्यानात्मक काल छोटो छ। कथाभित्र कहीं पनि साल, ऋतु, महिना, दिन जस्ता समयसूचक सड्केतहरू सूच्य छैनन् । कथाको प्रारम्भमा समाख्याताले दिनैपिच्छे छोरीलाई स्कुल पठाउनु र छोरीले पेटीबाँधी माग्नुलाई जीवन मानेको पाइन्छ। यस जीवनमा कुनै महान् कार्य गर्न नसके पनि छोरीको जामाको पेटी कसिदिएको सन्दर्भलाई समाख्याताले यसरी व्यक्त गरेको छ :

दिनैपिच्छे, छोरीलाई स्कुल पठाउनु, त्यसले मलाई आफ्नो पेटी बाँधी भागछ, त्यो स्कुल जान्छ, यै जीवन हो र यति मात्र जीवन हो। महान् कार्य गर्न सक्दै नसकुँला मैले, तर छोरीको जामाको पेटी म कसिदिन सक्छु, जति सक्छु त्यही जीवन हो। आज आजै सकिने कुरा (भविष्यत् हेरिरहन पर्देन), अर्को साल फेरि रोप्तु पर्ने मकै र आलुका बिउहरू, यी मात्रै जीवन र जीवनका सामग्री। अनेक थोक मिलाएर मान्छेले जीवनलाई बिख बनाइसकेको छ। (अनु. १) 
यस उद्गारमा बाँधी भाग्छ, स्कुल जान्छ, कसिदिन सक्छु, जति सक्छु, बनाइसकेको छ जस्ता अभूत कालिक क्रियापदहरू प्रयोग भएका छन् । यी समाख्यानात्मक क्रम हुन् । यिनलाई न्यारेटिभ सिक्वेन्स पनि भनिन्छ। कथाकारले न्यारेटिभ सिक्वेन्सलाई अग्रभूमिका रूपमा वर्णन गरेका छन् । कुन्ठिएको विचार पहिल्याउनु, फेरीवालले फेरी लाउँदा जाग्नु, फेरीवालले फेरी फुक्नु, घर वरिपरि घुम्दै गुन्गुनाउनु, म पात्रले गुनगुनाएको केही नबुकनु, कुकुर पनि चुप्प लागनु, फेरीवाल टाढा गइसकेको हुनु, समाख्याताले अकौ सुत्ने बल गर्नु (अनु. २-३) जस्ता घटनासम्मका कार्यहरू पनि अभूत कालिक क्रियाका रूपमा आएका छन् र यिनले पनि समाख्यानात्मक ऋमलाई नै अगाडि बढाएका छन् ।

प्रस्तुत कथामा सानोमा फेरीवाललाई सुन्दा समाख्याता डराउनु, बाबुका छेउमा पुग्नु, बाबुले भोलि बिहान हेर्नू भन्नु, फेरीवाल देखिन्छ भन्दा समाख्यातालाई निकै आश्चर्य लाग्नु, समाख्याताले दुलाबाट फेरीवाललाई हेर्नु, आमाको साल हो कि फेरीवालको सेतोसेतो लुगा देख्नु, हल्दी, चामल आदि फेरीवाललाई दिएकामा म पात्रले आमासँग सोध्नु र फेरीवालले भूतप्रेत धपाइदिने कुरा आमाले बताउनु, फेरीवाल पछि कुनै एक रात आउनु, आवाज ननिकालेर कयालको पर्दा च्यातेर म पात्रले चियाउनु, फेरीवाल ओरालै जानु, कुकुर डुर्रदुर्र गर्नु र एकपल्ट जस्तो भुक्नु, आफू जान्ने बुऊने र ठुलो भएपछि समाख्याताले फेरीवालसँग प्रश्न सोधन, फेरीवालले आफू शिवको अनुचर भएको बताउँदै "जहाँतक जोगी फेरी बजायै, उहाँ तककी रच्छे" पड्क्ति लेखाइदिनु (अनु. ४-१६) जस्ता कार्यहरू पृष्ठभूमि निर्माणका सन्दर्भमा आएका छन्। यी कार्यमा डराएको थिएँ, छेउमा पुगेको थिएँ, के के सोधँ, भन्नुभयो, अन्धकार लाग्यो, दुलोदेखि हेरें, लुगा देखें, आमासँग सोधँ,, आमाले भन्नुभयो, फेरीवाल आयो, पर्दा च्यातेर चियाएँ, ओरालै गयो, डुररुर्र गय्यो, एकपल्ट भुक्यो, बतायो, लेखाइदियो जस्ता क्रियापदहरू भूतकालिक हुन् र यी क्रियापदको प्रयोग कथाकारले अतीतको कार्यको वर्णनका सन्दर्भमा गरेका छन्। समाख्याता सिमाना बजार पुग्नु, ठेकेदारको वासमा जानु, कोठाभित्र पस्नु, मान्छे कुल्चनु, उभिएर रोकिनु, मान्छे नकराउनु न चल्नु, घरमालिकले फेरीवाल सुतेको बताउनु, म पात्रले जोगिएर पाइला चाल्नु जस्ता कार्यहरू पृष्ठभूमि निर्माणका निरन्तरतामा आएका छन्। यहाँ प्रयोग भएका सिमाना बजार पुगेको थिएँ, बासमा गयौं, भित्र पस्यौँ, मान्छे कुल्य्यो, रोकिएर उभिएँ, माम कराए, मान्छे, चलेन, जोगिएर पाइला चालें, रिसले कराएँ जस्ता क्रियापदहरू घटना वर्णनका क्रममा आएका छन्। यी क्रियापदले भूतकालीन स्थिति, मनोदशा र परिवेशको चित्रण गरेको पाइन्छ।

यस कथामा पहिलो राति फेरीवाललाई सुन्दा डराउनु र बाबुको छेउमा पुगनु (अनु. ४), हिमालयका काखमा बस्ने कुनै लौकिक व्यक्ति नै शिव हुनु, वीरत्वको युग हुनु, शरणागतलाई संरक्षण दिनु, चारैतिर फेरी फुक्नु, फेरीको आवाज पुग्ने ठाउँसम्म प्रतिद्वन्द्री हार मान्नु (अनु. १६), फेरीवालको सड्ख्या देख्दा समाख्यातालाई घिन लाग्नु, फेरीवालको सड्ख्या 'थुप्रै' र 'हरू' भएको सोच्नै नसक्नु, समाख्याताको अवधारणामा फेरीवाल एउटा हुनु, एक्लै हिंड्नु र अर्को फेरीवालका बारेमा थाहा नै नपाउनु (अनु. २५) स्थिति वर्णनसँग सम्बन्थित विषय हुन् । यसको प्रस्तुति डराएको थिएँ, पुगेको थिएँ, थियो, फुक्थ्यो, पुग्थ्यो, हार्दथ्यो, घिनलागदो लाग्यो, हुन सक्छ, सोच्न सकेको थिइनँ, हुन्थ्यो, हिंड्य्यो, थाहा पाएको हुँदैनथ्यो जस्ता पूर्ण, अभ्यस्त भूत एवम् पूर्ण वर्तमान कालीन क्रियारूपबाट गरिएको छ। यस्तै कथाकारले रमरमती डुल्दा रहेछन, मान्छे रहेछ, कराएछ, भनेछु, सोधेछु, ल्याएकी रहिछन्, चोइटिएको छैन रहेछ, सिड्गो मै रहने रहेछ, जस्ता अज्ञात भूतकालीन क्रियापदका रूप स्थितिवर्णनका क्रमा चित्रण गरेको देखिन्छ।

यस कथाको विस्तृत समय (काल) लामो भए पनि कथाकथन वा कथारेखाको समय स्पष्टतः किटान गरिएको छैन। समाख्याता सानोमा फेरीवालबाट डराएको घटनादेखि फेरीवाललाई ठगार घोषणा गरी इस्कुस दिँदासम्मका सन्दर्भमा २५-३० वर्षको अवधि अनुमान गर्न सकिन्छ तर कथारेखाका सन्दर्भमा 
भने समाख्याता छोरीलाई दिनैपिच्छे स्कुल पठाउनु, छोरीको जामामा पेटी बाँधिदिनु, सिमाना बजारमा ठेकेदारको घरमा फेरीवालहरू देख्नु, फेरीवालहरू धेरै भएकामा आफ्नो मनको वह सुके बजारमा भेटिएको दाजुलाई सुनाउनु, त्यसमा केही दिनपछि, घरमा आएको फेरीवाललाई नानीहरूकी आमाले दिन थालेका विभिन्न थोकहरू रोकी इस्कुस दिनुसम्मका घटनालाई मुख्य काल मान्न सकिन्छ। कथाकार राईले यस कथामा प्राकृतिकभन्दा व्यतिरेकी कालकर्म (अनु. ४-१६) अनुसरण गरेको देखिन्छ। यहाँ अग्रभूमि निर्माण वा समाख्यानात्मक ऋम निर्धारणमा अभूत कालिक क्रियाको प्रयोग गरिएको छ भने परिवेश, स्थिति र मनोदशाको वर्णन वा पृष्ठभूमि निर्माण भूतकालका विविध पक्षसहित पूर्ण वर्तमानकालिक क्रियासंरचनाको उपयोग गरिएको छ।

\section{समाख्यानमा कथनीयता}

समाख्यानात्मक कृतिमा देखापर्ने कुनै एक विन्दु, शिक्षा, दृष्टिकोण वा रुचिकर अनुभवलाई कथनीयता भनिन्छ। वास्तविक नभए पनि वास्तविक कै लाग्ने, समयातीत भएर पनि समयबद्ध भैं देखिने, स्थानातीत भएर पनि स्थान निर्दिष्टका रूपमा आख्यानात्मक सन्दर्भबाट कथनीयता स्पष्ट हुन्छ। यसका आधारभित्ति कार्य र चेतना गरी दुई किसिमका हुन्छन् । पात्रको अभिवृत्ति, लक्ष्य, माध्यम र कार्यवाट कथनीयता सड्केत हुन्छ । कार्यमा संलग्न पात्रले के जाने के जानेनन्, के विचार गरे के विचार गरेनन्, के अनुभव गरे के अनुभव गरेनन् बाट कथनीयताको खोजी गरिन्छ। यसको प्रभावकारितामा पहिचानात्मक दृष्टिकोणको विशिष्टता (स्रष्टा) र स्नेहशीलता (पाठक) देखापईन्। पहिचानको विशिष्टता आत्मस्वीकरण र इच्छापरिपूर्तिका माध्यमबाट हुने गई। पात्र र पाठकका अनुभवबिच सामज्जस्य भएमा आत्मस्वीकरणका माध्यमबाट पहिचान स्थापित हुन्छ। पात्र र पाठकका बिचको अनुभवमा समानता हुँदा आत्मस्वीकरण र असमानताबाट इच्छापरिपूर्तिका माध्यमबाट हुने पहिचानको चिनारी हुन्छ।

प्रस्तुत कथाको कथनीयता मान्छेले आदर्शलाई पन्छूयाएर यथार्थ वा प्राकृतिक जीवन बाँच्नुपछ भन्ने हो । जीवन आदर्शबाट घेरिएको छ। जीवन भोगाइका ऋममा धर्म, राष्ट्रियता, सच्चरित्रता, साहित्यिकता जस्ता पक्षहरू आदर्शको घुम्तीमा लुटपुटिएका छन्। उहिले मान्छेसँग आदर्श थिएन। ऊ साँचो र पूर्णजीवन बाँच्थ्यो। आज मान्छे, आफूलाई सर्वश्रेष्ठ बनाउन चाहन्छ र विभिन्न मतवादको अनुसरण गर्दै रित्तिदै गएको छ। विश्लेष्य कथामा पनि समाख्याता फेरीवालसँग डराएको, बाबुसँग प्रश्न सोधेको, ऊयालबाट लुकेर फेरीवाललाई हेरेको, फेरीवालसँगको भेटमा जिज्ञासा राखेको, शिवको अनुचर भएकाले भूतप्रेत फेरीवालले हटाइदिन्छ भन्ने मान्यता अँगालेको, ठेकेदारको घरमा फेरीवालहरूको दुर्दशा देखेपछि, आश्चर्यमा परी घृणा व्यक्त गरेको र कथाको अन्त्यतिर घरमा आएको फेरीवाललाई इस्कुस टिपेर दिन्छ। यी घटनाबाट समाख्याताको फेरीवालप्रतिको धारणा र त्यसमा आएको परिवर्तन अनुभव गर्न सकिन्छ। यस परिवर्तनबाट मान्छेका जेजस्ता आदर्श र सिद्धान्तहरू छन् ती बुऊदै जाँदा समाप्त हुँदै गएका छन् । आदर्शविनाको मान्छे पनि मान्छे नै हो। समाख्याताले दिएको इस्कुस फेरीवालाले तिरस्कार गरेको छ। यस सम्बन्धमा समाख्याताको भनाइ छ, "जीवन तर त्यसै बाँचिन्छ, यसमा आदर्श र सिद्धान्तहरूले अर्थ हाल्नुपर्देन" (अनु. ३३)। यहाँ जीवनानुभवको सामान्य घटनालाई लिएर त्यसको गहिराइमा पुगी वैचारिक निष्कर्ष दिने प्रयास गरिएको छ। यसबाट समाख्याताको समस्या भए पनि त्यसलाई जुन वैचारिक उचाइ प्रदान गरिएको छ, सार्वकालिक सार्वदेशिक बन्न गएको छ। यसरी प्रस्तुत कथामा मान्छेले अरूका धारणाबाट भन्दा पनि स्वानुभवबाट जीवनको अर्थ लगाउन सक्छ भन्ने समाख्यानात्मक कथनीयता प्रकट भएको छ। 


\section{निष्कर्ष}

कथाकार इन्द्रबहादुर राईद्वारा रचित 'एउटा विचारको यात्रापथ' कथामा समाख्याता 'म' पात्रका रूपमा आएको छ। यसमा समाख्यानात्मक तहमा गैर आख्यानात्मक, आख्यानात्मक र कार्यात्मक गरी तिन तह रहेका छन्। गैर आख्यानात्मक तहमा स्रष्टा राई र पाठकका बिचको सज्चार रहेको छ। आख्यानात्मक तहमा समाख्याता र सम्बोधित रहेका छन् । यहाँ सम्बोधित अज्ञात र निष्किय छ भने समाख्याताले ९० प्रतिशतभन्दा बढी भाग ओगटेको छ। कार्यात्मक तहमा पात्रपात्रका बिचको संवाद अन्तर्अख्यानका रूपमा आएको छ। समाख्याताले आफ्नो विचार, धारणा वा दृष्टिकोणलाई प्रभावकारी बनाउन यस तहको उपयोग गरेको देखिन्छ। यस कथामा समाख्याताका दृष्टिकोण जसरी आएका छन्, त्यसरी अरू पात्रका दृष्टिकोण वा चिन्तन आएका छैनन् । अरू पात्रहरू समाख्याताको सूचनालाई पुष्टि गर्न मात्र आएका छन्। त्यसैले यस कथामा पाठात्मक वाच्यता उच्च रहेको छ। आफैं आख्यानमा उपस्थित भई घटनाको साथीसमेत भएकाले प्रस्तुत कथाको समाख्याता स्वकथनात्मक प्रकृति रहेको छ। आख्यानको अधिकांश कार्ययोजना र वैचारिक जीवनमा आएको परिवर्तन र त्यसको व्याख्याता (भोक्तृता) वा समाख्याता स्वयम् भएकाले यो खुला र पाठकमैत्री समाख्यान पनि हो । त्यस्तै प्रस्तुत कथामा फेरीवालप्रति गरिएको टिप्पणी र मूल्याङ्कनबाट समाख्याता खुला रहेको देखिन्छ। यस कथाको सङ्केन्द्रक वा फोकलाइजर समाख्याता आफै हो र उसको जीवन र जोगीसम्बन्धी चिन्तनमा आएको परिवर्तन र प्राकृतिकताप्रतिको मोहलाई सड्केन्द्रणीय पक्ष/विषयका रूपमा लिन सकिन्छ। त्यस्तै प्रस्तुत कथामा समाख्यानात्मक कालको क्रमका रूपमा अभूत काल आएको छ, र यो आख्यानात्मक ऋमको सूचक वा अग्रभूमि निर्माण हो। कालिक स्थिति, परिवेश, मनोदशा, स्मृति आदि वर्णन वा पृष्ठभूमि निर्माणका निम्ति विवेच्य कथामा भूतकालीन सन्दर्भको प्रयोग गरिएको छ। त्यस्तै प्रस्तुत कथामा मान्छेले आदर्शलाई पन्छाएर प्राकृतिक जीवन बाँच्नुपछ भन्ने कथनीयता प्रकट भएको छ। समाख्याताका जीवनको सामान्य घटनालाई लिई त्यसको गहिराइमा पुगी अरूका धारणाबाट भन्दा पनि आफ्नै अनुभवबाट जीवनलाई अर्थ्याउन सकिन्छ भन्ने आशय प्रस्तुत कथामा प्रकट भएको देखिन्छ ।

\section{सन्दर्भ सामग्रीसूची}

गौतम, देवीप्रसाद (२०६९), 'समाख्यानात्मक वाच्यत्व', प्राज्ञिक संसार, वर्ष १, अङ्क ६, प्. १-६ ।

न्यौपाने, नेत्रप्रसाद (२०६९), 'खीर कथाको समाख्यानशास्त्रीय विश्लेषण', प्राज्ञिक संसार, वर्ष १, अड्क ६, पृ. ช२-૪७।

पौडेल, नवराज (२०७०), 'मैले नजन्माएको छोरो कथाको समाख्यानशास्त्र', प्राजिक संसार, वर्ष १, अड्क १०, पृ. ชपू-पू।

राई, इन्द्रबहादुर (२०६३), 'एउटा विचारको यात्रापथ', नेपाली कथा र उपन्यास, बराल, कृष्णहरि र एटम, नेत्र (सम्पा.), काठमाडौं : अक्सफोर्ड इन्टरनेसनल पब्लिकेसन ।

शर्मा, यादव (२०६९), 'मैले सरिताको हत्या गरें समाख्यानशास्त्र', प्राजिक संसार, वर्ष १, अड्क ६, पृ. १७-२१ । 